\title{
The Protocol on Strategic Environmental Assessment: A Matter of Good Governance
}

\author{
Jan De Mulder
}

In this article, the Strategic Environmental Assessment (SEA) Protocol to the Espoo Convention is introduced and analyzed. As an outcome of international processes aimed at the institutional adoption of sustainable development policy, the need for strategic environmental assessment has become obvious given the experiences with environmental impact assessment as an effective environmental policy tool for projects. The introduction of SEA and the adoption of a specific international legal instrument are also situated within ongoing international good governance and (new) public management developments which aim at improving decision making. In this context, the application of SEA and the SEA Protocol is analyzed focusing on its features, approaches and opportunities.

\section{INTRODUCTION}

The adoption of the United Nations Economic Commission for Europe (UNECE) Protocol on Strategic Environmental Assessment (SEA) to the UNECE Espoo Convention ${ }^{1}$ by 35 States and the European Community illustrates the international institutionalization of the 'ecologization of governance' ${ }^{2}$ with SEA as one of its dominant instruments. The SEA Protocol fits into the expansion of multilateral environmental agreements as part of global sustainable development policy infrastructure. Within the three classic (environmental, economic, social) sustainable development pillars, a further 'institutional' pillar plays a crucial role. The Brundtland Report stressed this feature with a particular focus on good governance. ${ }^{3}$ This article aims to

\footnotetext{
${ }^{1}$ United Nations Economic Commission for Europe (UNECE) Protocol on Strategic Environmental Assessment (SEA) to the UNECE Espoo Convention (Kiev, 21 May 2003), found at <http:// www.unece.org/env/eia/sea_protocol.htm>.

${ }^{2}$ See J. Holder, Environmental Assessment: The Regulation of Decision Making (Oxford University Press, 2004), at 17. 'Ecologization of governance' in a European context has been described as 'absorption of the ideas and language of environmental policy into the core of the EU's constitution and policy formulation processes. See D. McGillivray and J. Holder, 'Locating EC Environmental Law', 20:1 Yearbook of European Law (2001), 139, at 139.

${ }^{3}$ S. Pfahl, 'Institutional Sustainability', 8:1/2 Int. J. Sustainable Development (2005), 80. See also G. D'Alisa, 'Dimensions of Sustainable Development: A Proposal of Systematization of Sustainable Approaches', 9 Quaderno (2007), 1, at 12, found at <http://www.
}

introduce SEA, focusing on its (good) governance features, objectives and opportunities. After a rather theoretical introduction, the genesis and the contents of the SEA Protocol will be explored and critically reviewed. Some governance issues regarding the role of public authorities and other stakeholders for the implementation of the SEA Protocol will get particular attention. The final part of the article deals with SEA concerns with respect to quality assurance rules, integrated assessments and quality management.

\section{SEA: WHY AND WHAT?}

The need for SEA has been justified from different angles and levels. The SEA instrument is viewed as a means to remedy the limited effectiveness of environmental impact assessment (EIA) of projects given the sometimes unsatisfactory outcomes of this bottom-up approach. ${ }^{4}$ SEA is also an element in the international policy evolution towards a (top-down) framework of sustainable development institutions and tools. ${ }^{5}$ The importance of SEA has been acknowledged by the Organization for Economic Cooperation and Development (OECD) regarding, inter alia, its role in development

\footnotetext{
dsems.unifg.it/q092007.pdf>, who states: 'to these three dimensions we add a fourth institutional one which is participative democracy'; and H. Abaza and A. Baranzini, 'Introduction', in Implementing Sustainable Development: Integrated Assessment and Participatory Decision-making Processes (UNEP/Edward Elgar, 2002), 1, at 2, who state that 'sustainability is also related to the debate on governance and participatory approaches'. The Council of Europe published in 2011 a stocktaking report on the notions of 'good governance' and 'good administration'. See European Commission for Democracy through Law (Venice Commission), Study No. 470/2008 (CDL-AD(2011)009, 2008), found at <http://www.venice.coe.int/docs/ 2011/CDL-AD(2011)009-e.pdf>.

${ }^{4}$ R. Van der Vorst, A. Grafé-Buckens and W. R. Sheate, 'A Systemic Framework for Environmental Decision-making', 1:1 J. Environmental Assessment Policy and Planning (March 1999), 1, at 23, state that: 'The question of need has always been problematic in EIA since many options have been foreclosed by the time an EIA is carried out for an individual proposed development. EIA has struggled, in the absence of SEA, to address this issue effectively. In SEA, the question of need is central to sustainable development objectives.'

${ }^{5} \mathrm{R}$. Therivel et al., Strategic Environmental Assessment (Earthscan, 1992), at 19-22.
} 
cooperation. Applying SEA may support the integration of environment and development, identify unexpected potential impacts of reform proposals, improve the identification of new opportunities, prevent costly mistakes, build public engagement in decision making for improved governance, facilitate transboundary cooperation and safeguard environmental assets for sustainable development and poverty reduction. ${ }^{6}$

In practice, SEA includes a number of stages. ${ }^{7}$ The first stage is the establishment of the context for the SEA, including the screening (whether a SEA is required or necessary) and baseline data gathering. The second stage addresses implementation. This includes a range of activities, including deciding on the scope of the SEA (in dialogue with stakeholders); collecting baseline data (if not done in the first stage); identifying or developing (policy) alternatives; assessing the effects of the plan, programme or policy; identifying how to enhance opportunities and mitigate impacts; quality assurance; and reporting. The third stage includes consultation on the draft plan, programme or policy and the drafting of a report to inform and influence decision making. This includes the formulation of recommendations (in dialogue with stakeholders). The fourth and final stage focuses on monitoring and evaluating the implementation of the plan (and evaluation of the SEA).

Transparency and accountability in decision making are key attributes of SEA, ${ }^{8}$ as is its 'informative' role. ${ }^{9}$ Brown and Therivel define SEA as:

A process directed at providing the authority responsible for policy development (the 'proponent') (during policy formulation) and the decision-maker (at the point of policy approval) with a holistic understanding of the environmental and social implications of the policy proposal (= strategic action), expanding the focus well beyond the issues that were the original driving force for new policy. ${ }^{10}$

\footnotetext{
${ }^{6}$ Organization for Economic Cooperation and Development (OECD), Applying Strategic Environmental Assessment: Good Practice Guidance for Development Co-operation (OECD, 2006), at 41.

${ }^{7}$ Ibid., at 54. See also Friends of the Earth, Strategic Environmental Assessment (SEA): A Campaigner's Guide (Friends of the Earth, October 2005), at 3, found at <http://www.foe.co.uk/resource/guides/ strategic_env_assessment.pdf>.

${ }^{8}$ S. Nooteboom, 'Impact Assessment Procedures for Sustainable Development: A Complexity Theory Perspective' 27:7 Environmental Impact Assessment Review (2007), 645, at 661-2.

${ }^{9}$ See J. Holder, n. 2 above, at 15.

${ }^{10} \mathrm{~A}$. Brown and R. Therivel, 'Principles to Guide the Development of Strategic Environmental Assessment Methodology', 18:3 Impact Assessment and Project Appraisal (September 2000), 183, cited in B. Dalal-Clayton and B. Sadler, Strategic Environmental Assessment: A Sourcebook and Reference Guide to International Experience (Earthscan/IIED, 2005), at 11. See also B. Sadler and R. Verheem, Strategic Environmental Assessment: Status, Challenges and Future Directions (Ministry of Housing, Spatial Planning and the Environment/ DHV, 1996), at 27.
}

This definition includes core elements of the (good) governance concept, which refers to structures as well as to processes.

One 'structural' governance approach is 'New Public Management' (NPM), ${ }^{11}$ which is linked to the paradigms of efficiency and effectiveness. ${ }^{12}$ NPM is commonly considered as the transfer of business and market principles and management techniques from the private into the public sector, symbiotic with and based on a neoliberal understanding of State and economy. ${ }^{13}$ The post-NPM developments towards 'new governance ${ }^{14}$ or 'whole of government ${ }^{15}$ focus on coordination, coherence and steering, ${ }^{16}$ as well as also public values. ${ }^{17}$ Environmental assessment is considered as a 'new governance' approach as it is considered as a means to secure participation, encourage information exchange, foster partnerships and joint responsibility and, as such, to improve decision making by making bureaucracies and governments 'think'. ${ }^{18}$

Improving strategic action and promoting the participation of stakeholders are core objectives of

${ }^{11} \mathrm{~T}$. Christensen and P. Lagreid, 'Increased Complexity in Public Organizations: The Challenges of Combining NPM and post-NPM', in P. Lagreid and K. Verhoest (eds), Governance of Public Sector Organizations: Proliferation, Autonomy and Performance (Palgrave Macmillan, 2010), 255, at 258, which states that 'these NPM reform ideas produced a more fragmented public-sector model. They introduced more complexity, partly because elements from the 'old public administration' did not disappear, but were modified and combined with NPM elements.'

${ }^{12} \mathrm{G}$. Berger, 'Reflections on Governance: Power Relations and Policy Making in Regional Sustainable Development', 5:3 J. Environmental Policy and Planning (September 2003), 219, at 220-1.

${ }^{13} \mathrm{~W}$. Drechsler, 'The Rise and Demise of the New Public Management', 33 Post-Autistic Economics Review (2005), 17, at 17, found at $<$ http://www.paecon.net/PAEReview/issue33/Drechsler33.htm>

${ }^{14}$ See S. Baker, In Pursuit of Sustainable Development: A Governance Perspective (International Conference of the European Society for Ecological Economics, 2009).

${ }^{15}$ At the Meeting of the OECD Public Governance Committee in Venice on 15 November 2010, the Ministers favoured not only more transparent governments and citizen's participation, but they also were '[s]upporting a whole-of-government perspective through strategic coordination and policy coherence'. See Communiqué from the Meeting of the OECD Public Governance Committee at Ministerial Level 'Towards Recovery and Partnership with Citizens: The Call for Innovative and Open Government' (Venice, 15 November 2010), found at <http://www.vm.fi/vm/en/04_publications_and_documents/ 03_documents/201011230ECDMi/oecd_ministerial_meeting_final_ communique_151110.pdf>.

${ }^{16} \mathrm{~J}$. Halligan, 'Post-NPM Responses to Disaggregation through Coordinating Horizontally and Integrating Governance', in P. Laegreid and K. Verhoest, n. 11 above, at 241

17 J. O'Flynn, 'From New Public Management to Public Value: Paradigmatic Change and Managerial Implications', 66:3 Australian J. Public Administration (2007), 353, at 362, who states: '[T]his will place considerable strain and pressure on public officials through increased emphasis on consultation, communication, deliberation and ultimately defining public value.'

${ }^{18} \mathrm{~J}$. Holder and D. McGillivray, 'Taking Stock', in Taking Stock of Environmental Assessment: Law, Policy and Practice (Routledge, 2007), 1, at 5. 
SEA. ${ }^{19}$ Benefits of SEA for improving environmental governance ${ }^{20}$ include: promoting integrated decision making (focusing on environmental, social and sustainable development); facilitating the design of sustainable policies and plans; facilitating consideration of alternatives; taking account of cumulative effects; enhancing institutional efficiency and administrative legitimacy; increasing transparency by involving stakeholders; increasing influence from other sector policies and enhancing coordination; streamlining project assessments; and providing a mechanism for public engagement and building trust.

For politicians, the use of SEA may create more credibility and easier implementation of improved decisions and plans, as well as the possibility to avoid (often costly) mistakes or deadlocks. SEA has the potential to improve governance because it systematically questions the environmental quality of strategic decisions. ${ }^{21}$

Like EIA, SEA was originally conceived as a technical instrument to provide decision-makers with reliable information. However, planning approaches and decision making generally lack scientific stability and are constantly influenced by uncertainty, conflict and ambiguity..$^{22}$ So there is a growing understanding that SEA needs to be adapted to become 'a positive constructive force in policy formation, contributing to efficiency, legitimacy and general quality in decision-making. ${ }^{23}$

${ }^{19} \mathrm{R}$. Therivel, Strategic Environmental Assessment in Action (Earthscan, 2004), at 8. See also T. Fischer, Strategic Environmental Assessment in Transport and Land Use Planning (Earthscan, 2002), at 10-11; and E. João, 'Key Principles of SEA', in M. Schmidt, E. João and E. Albrecht (eds), Implementing Strategic Environmental Assessment (Springer, 2005), 1 , at 9.

${ }^{20}$ See R. Therivel et al., n. 5 above, at 19-22. See also World Bank, Strategic Environmental Assessment in Policy and Sector Reform: Conceptual Model and Operational Guidance (IBRD/World Bank, 2011), at 73 .

${ }^{21}$ R. Jiliberto Herrera, 'The Contribution of Strategic Environmental Assessment to Transport Policy Governance', OECD-Joint Transport Research Centre Discussion Paper 2009-30 (December 2009), at 10, found at <http://www.internationaltransportforum.org/jtrc/ DiscussionPapers/DP200930.pdf>. See also E. Gualmini, 'Restructuring Weberian Bureaucracy: Comparing Managerial Reforms in Europe and the United States', 86:1 Public Administration, 75, at 76. She identifies three NPM trends: reforms of the formal structure of administration, the organization of the civil service and 'administrative procedures and processes'. Strategic Environmental Assessment falls within the third category.

${ }^{22}$ M. Nilsson and R. Jiliberto, 'SEA and Decision-making Sciences', in P. Caratti, H. Dalkmann and R. Jiliberto (eds), Analysing Strategic Environmental Assessment: Towards Better Decision-making' (FEEM/Edward Elgar, 2004), at 35.

${ }^{23} \mathrm{~V}$. Lobos and M. Partidario, 'Rationale behind the Current Practice in Strategic Environmental Assessment (SEA)', found in IAIA10 Conference Proceedings: The Role of Impact Assessment in Transitioning to the Green Economy, 30th Annual Meeting of the International Association for Impact Assessment, 6-11 April 2010, International Conference Centre Geneva (IAIA, 2010), found at <http://www.iaia.org/iaia10/documents/reviewed_papers/Rationale $\% 20$ Behind $\% 20$ the $\% 20$ Current\%20Practice $\% 20$ in\%20SEA.pdf .

See also M. Partidario, 'Impact Assessment in Transition: Keeping
The development within the World Bank of Institutioncentred Strategic Environmental Assessment (I-SEA) is an effort to address this challenge. ${ }^{24}$ Central to the I-SEA approach is that in order for SEA to be effective at the policy level, it should be centred on assessing institutions and governance systems that underlie environmental and social management rather than on predicting impacts of alternative policy actions. ${ }^{25}$

\section{THE SEA PROTOCOL}

The SEA Protocol is the only multilateral agreement that deals exclusively with environmental assessment requirements at a strategic or planning level. Its 'mother convention', the UNECE Espoo Convention, ${ }^{26}$ provides for the 'voluntary' application of SEA. Article 2(7) of the Convention states:

Environmental impact assessments as required by this Convention shall, as a minimum requirement, be undertaken at the project level of the proposed activity. To the extent appropriate, the Parties shall endeavour to apply the principles of environmental impact assessment to policies, plans and programmes. ${ }^{27}$

In 1992, the Espoo Convention Secretariat published a report on the application of EIA principles to policies, plans and programmes. ${ }^{28}$ The report was prepared by a task force under the lead of the United States and included four North American SEA examples out of the ten case studies. Subsequently, SEA provisions and decisions were adopted and incorporated into various international treaties. ${ }^{29}$ These developments led to the emergence of international political will to negotiate a protocol to the Espoo Convention focusing on SEA.

Accountable in Collaborative Learning Processes' (3 May 2011), found at <http://www.sume.at/webfm_send/134>.

${ }^{24}$ D. Slunge et al., Conceptual Analysis and Evaluation Framework for Institution-centred Strategic Environmental Assessment (University of Gothenburg, 2009).

${ }^{25}$ World Bank, Institution Centered SEA (World Bank, undated), found at <http://siteresources.worldbank.org/ENVIRONMENT/Resources/ 244380-1236266590146/institutionalcenteredsea.pdfs.

${ }^{26}$ Convention on Environmental Impact Assessment in a Transboundary Context (Espoo, 1991), found at <http://www.unece.org/ env/eia/about/eia_text.html>.

${ }^{27}$ Ibid.

${ }^{28}$ UNECE, Application of Environmental Impact Assessment Principles to Policies, Plans and Programmes, UNECE Series 5 (January 1992), found at $<$ http://www.unece.org/env/eia/publications15.html>. ${ }^{29}$ See, for example, CBD Decision VI/7 on Identification, monitoring, indicators and assessments of COP 6 of the Convention on Biological Diversity (UNEP/CBD/COP/6/20, 23 September 2003), found at $<$ http://www.cbd.int/decision/cop/?id=7181>. See also S. Marsden, Strategic Environmental Assessment in International and European Law (Earthscan, London, 2008), at 115. For non-legal instruments that have been adopted, see, for example, the EIA guidelines for the Arctic region, described in T. Koivurova, The Importance of International Environmental Law in the Arctic (Arctic Centre, undated), found at <http://www.arcticcentre.org/InEnglish/ARCTIC_REGION/Articles/ Environmental_law.iw3>. 


\section{SEA PROTOCOL NEGOTIATIONS}

The formal decision to start negotiations on a SEA protocol was taken at the Second Meeting of the Parties to the Espoo Convention (Sofia, 27-28 February 2001). The future protocol was envisaged as a separate legal instrument. ${ }^{30}$ In addition to the Espoo Convention, particular considerations regarding the relationship between EIA and health impact assessment, ${ }^{31}$ as well as the requirements and features of the UNECE Aarhus Convention, ${ }^{32}$ played an important role during the negotiations.

The start of the negotiations was characterized by scepticism - particularly within the European Union (EU) group. The difficult legislative process to approve the EU's SEA Directive (Directive 2001/42/EC) ${ }^{33}$ undermined the willingness of a majority of EU Member States to re-open similar discussions in a multilateral forum. The major concern not to go beyond the

\footnotetext{
${ }^{30}$ For an analysis of the international legal context of the SEA Protocol, n. 1 above, see S. Marsden, 'SEA and International Law: An Analysis of the Effectiveness of the SEA Protocol to the Espoo Convention, and of the Influence of the SEA Directive and Aarhus Convention on Its Development', 1 Environmental Law Network (ELNI) Review (2002), 1, at 1.

${ }^{31}$ This was reflected by the active involvement of the World Health Organization in the negotiations based, inter alia, on the political commitments made in the Declaration of the Third Ministerial Conference on Environment and Health (London, 16-18 June 1999), found at <http://www.euro.who.int/_data/assets/pdf_file/0007/88585/E69046. pdf $>$. At this meeting a proposal was even tabled to start work on Strategic Environmental Assessment under the Aarhus Convention. The final London Declaration on Action in Partnership stated:
}

7. We will carry out environmental impact assessments fully covering impacts on human health and safety. We invite countries to introduce and/or carry out strategic assessments of the environment and health impacts of proposed policies, plans, programmes and general rules. We invite international financial institutions also to apply these procedures. There will be appropriate participation of nongovernmental organizations (NGOs) and members of the public in the procedures set out in this paragraph.

${ }^{32}$ Convention on Access to Information, Public Participation in Decision-making and Access to Justice in Environmental Matters (Aarhus, 25 June 1998), found at <http://www.unece.org/env/pp/ treatytext.html>.

${ }^{33}$ Directive 2001/42/EC of the European Parliament and of the Council of 27 June 2001 on the assessment of the effects of certain plans and programmes on the environment, [2001] OJ L197/30, found at $<$ http://ec.europa.eu/environment/eia/sea-support.htm>. For analyses of the SEA Directive, see J. De Mulder, 'The New Directive on Strategic Environmental Assessment', 1 ELNI Review (2001), 14, at 15 , found at <http://www.oeko.de/elni/PDF-Files/Archive_elni issues/elni-Review\%201-2001.pdf $>$; F. Haumont, 'La directive 2001/ 42/CE du 27 juin 2001 relative à l'évaluation des incidences de certains plans et programmes sur l'environnement: quelques bouleversements en perspective', 4 Aménagement-Environnement (2001), 298; L. Feldmann, M. Vanderhaegen and C. Pirotte, 'The EU's SEA Directive: Status and Links to Integration and Sustainable Development', 21:3 Environmental Impact Assessment Review (2001), 20322; and L. Feldmann, 'Strategische Umweltprüfung (SUP) - Zwei Drittel des Weges zur EG-Richtlinie geschafft', 2 UVP-report (2000), 109 contents of the SEA Directive would become the guiding principle for almost all EU interventions during the meetings. Furthermore, some delegations had the impression that the Secretariat acted as the spokesman for nongovernmental organizations (NGOs) rather than as a coordinating body for negotiations. ${ }^{34}$

Many NGOs regarded the SEA Protocol negotiation process as an opportunity to strengthen the Aarhus outcome in a specific instrument and strove for a comprehensive instrument that would provide for broad public participation and access to justice in strategic decision making. ${ }^{35}$ Representatives from various newly independent States and countries in transition (CITs) voiced similar views, but the fact that several of these CITs were on the brink of becoming part of the EU did not bolster outspoken positions in the end. However, these opposing views would become the major feature of the negotiations.

\section{SUBSTANTIVE PROVISIONS OF THE SEA PROTOCOL}

As a protocol to the Espoo Convention, the SEA Protocol reflects the same horizontal character as its parent, containing essentially procedural requirements. Regarding its contents and structure, the SEA Protocol and the EU's SEA Directive share many elements. The objective of SEA based on the Directive, as well as the Protocol, is for decision-making processes to follow specific and previously determined chains of actions. ${ }^{36}$ While the SEA Directive has a straightforward link to

${ }^{34}$ L.E. Susskind, Environmental Diplomacy: Negotiating More Effective Global Agreements (Oxford University Press 1994), at 59.

${ }^{35}$ The tension between the NGO world and the European Commission was highlighted by a press release from the European Environmental Bureau (EEB) on 27 March 2002, referred to in J. De Mulder, 'Environmental Assessment in International Law: The "Impact" of the Espoo Convention, the SEA Protocol and Others', in T. Ormond, M. Führ and R. Barth (eds), Environmental Law and Policy at the Turn to the $21^{\text {st }}$ Century/Umweltrecht und - politik an der Wende zum 21. Jahrhundert (Lexxion, 2006), 97, at 112. The EEB accused the Commission of being 'conservative': 'According to the EEB, the Protocol should go beyond the EU Directive, particularly with regards to:

\footnotetext{
- allowing public participation at an early stage (in screening and scoping),

- providing adequate notification of the public, and

- including preparation of policy and legislation/legal acts in the

scope of the Protocol.
}

This approach would be more consistent with the Aarhus Convention's provisions and also with the public's expectations to fully participate in environmental decision-making processes and contribute to improving Europe's environment'.

${ }^{36}$ See R. Jiliberto, 'Setting the Ground for a New Approach to SEA', in P. Caratti, H. Dalkmann and R. Jiliberto (eds), Analysing Strategic Environmental Assessment: Towards Better Decision Making (Edward Elgar, 2004), at 21. For a more detailed analysis of the SEA Protocol, see J. Jendroska and S. Stec, 'The Kyiv Protocol on Strategic Environmental Assessment', 33:3-4 Environmental Policy and Law (2003), 99, at 105; J. De Mulder, 'The New UNECE Protocol on 
the EIA Directive (Directive 85/337/EEC as amended by Directive 97/1/EC, Directive 2003/35/EC and Directive $2009 / 31 / \mathrm{EC}),{ }^{37}$ the SEA Protocol is a stand-alone instrument, as its link with the Espoo Convention is mainly restricted to 'organizational' matters.

The SEA Protocol contains 26 articles and five annexes. The substantive articles address: the objective (Article 1); definitions (Article 2); general provisions (Article 3); field of application concerning plans and programmes (Article 4; Annexes I and II); screening (Article 5; Annex III); scoping (Article 6); the environmental report (Article 7; Annex IV); public participation (Article 8; Annex V); consultation with environmental and health authorities (Article 9); transboundary consultations (Article 10); the decision (Article 11); monitoring (Article 12); policies and legislation (Article 13); Meeting of the Parties to the Convention serving as the Meeting of the Parties to the Protocol (Article 14); and relationship to other international agreements (Article 15). ${ }^{38}$

Article 1 describes the objective of the SEA Protocol as providing for a high level of protection of the environment, including health, and gives means by which the objective can be realized. It states:

The objective of this Protocol is to provide for a high level of protection of the environment, including health, by:

(a) ensuring that environmental, including health, considerations are thoroughly taken into account in the development of plans and programmes;

Strategic Environmental Assessment', 2 ELNI Review (2003), 1, at 13 ; and S. Marsden, n. 29 above, at 93, which offers a very comprehensive overview.

${ }^{37}$ This link is through Article 3 of the SEA Directive, n. 34 above (regarding the area of application). For the texts and additional information on the EIA Directive and the SEA Directive, see Council Directive of 27 June 1985 on the assessment of the effects of certain public and private projects on the environment (85/337/EEC), [1985] OJ L 175/40, amended by Council Directive 97/11/EC of 3 March 1997 amending Directive 85/337/EEC on the assessment of the effects of certain public and private projects on the environment, [1997] OJ L 73/5, Directive 2003/35/EC of the European Parliament and of the Council of 26 May 2003 providing for public participation in respect of drawing up of certain plans and programmes relating to the environment and amending with regard to public participation and access to justice Council Directives 85/337/EEC and 96/61/EC on the geological storage of carbon oxide and amending Council Directive 85/337/EEC, European Parliament and Council Directives 2000/ 60/EC, 2001/80/EC, 2004/35/EC, 2006/12/EC, 2008/1/EC and Regulation (EC) No 1013/2006, [2003] OJ L 156/17; and Directive 2009/31/EC of the European Parliament and of the Council of 23 April 2009, [2009] OJ L 140/114 - all found at <http://ec.europa.eu/ environment/eia/eia-legalcontext.htm>.

${ }^{38}$ See SEA Protocol, n. 1 above. Articles 16-26 concern treaty law aspects: right to vote (Article 16); secretariat (Article 17); annexes (Article 18); amendments to the Protocol (Article 19); settlement of disputes (Article 20); signature (Article 21); depository (Article 22); ratification, acceptance, approval and accession (Article 23); entry into force (Article 24); withdrawal (Article 25); and authentic texts (Article 26). (b) contributing to the consideration of environmental, including health, concerns in the preparation of policies and legislation;

(c) establishing clear, transparent and effective procedures for strategic environmental assessment;

(d) providing for public participation in strategic environmental assessment; and

(e) integrating by these means environmental, including health, concerns into measures and instruments designed to further sustainable development.

Careful reading of the recommended means makes clear that only one of these components (elaborated in (c)) is really required: the establishment of clear, transparent and effective SEA procedures. Whilst (a) and (b) do not concern technical means, the requirement for transparency is repeated by the public participation requirement (d). It is quite obvious that public participation is the major opportunity to safeguard transparency. The last item (e) seems more inspired by the need to have at least a reference to sustainable development rather than by a concern to have a more or less logical phrase. ${ }^{39}$ One may expect that measures and instruments 'designed to further sustainable development' should already have integrated environmental concerns, especially since (as stated in Article 1) SEA has already been described as a tool for environmental protection. Although the considerations in the Preamble refer to the outcomes of the 2002 World Summit on Sustainable Development (Johannesburg 2002), ${ }^{40}$ the objective of the SEA Protocol is not clearly situated within a policy framework aimed at sustainable

${ }^{39}$ The original objective provision in the draft SEA Protocol (Draft Elements for a Protocol on Strategic Environmental Assessment, Note by the Secretariat (MP.EIA/AC.1/2001/3, 8 March 2001), found at $<$ http://www.unece.org/env/eia/ahwg_sea1.html>) did not contain a reference to sustainable development but situated the SEA requirements in a wider environmental and health policy approach and linked the introduction of a SEA approach to the requirement to establish policy objectives within the strategic decision making. It stated:

In order to promote at all appropriate levels, nationally, regionally and locally as well as in transboundary and international contexts, the protection of the right of every person of present and future generations to live in an environment adequate to his or her health and well-being and the highest level of protection of the environment and environment-related health, each Party shall establish environmental protection and health objectives in accordance with relevant international agreements and shall ensure that these objectives form an integral part of strategic decision-making, with public participation, by establishing a strategic environmental assessment mechanism in accordance with the provisions of this Protocol.

The SEA Directive (ibid.) also contains a reference to environmental protection objectives established at the national or international level. These objectives should be used as part of the assessment criteria or framework for the particular SEA work (Annex I, sub (e)). However, the SEA Directive does not require, or is not aimed at, introducing such objectives.

${ }^{40}$ Report of the World Summit (Johannesburg, 26 August-4 September 2002) on Sustainable Development (A/CONF.199/20, 4 
development. Given the absence of SEA in the Johannesburg Plan of Implementation, perhaps one should not be surprised. ${ }^{41}$

Article 2 contains eight definitions..$^{42}$ The definition of 'plans and programmes' is essentially identical to the one in the SEA Directive. The definition of 'strategic environmental assessment' includes most elements found in the definition of 'environmental assessment' in the SEA Directive (preparation of an environmental report, carrying out of consultations and the taking into account of the report and the consultations in the decision making), and is much more elaborate compared to the definition of 'environmental impact assessment' in the Espoo Convention. The SEA Protocol definition also has some additional elements. Specifically, it includes the 'technical heart' of an impact assessment: 'the evaluation of the likely environmental, including health, effects' and links to this 'the determination of the scope of an environmental report', which seems to be rather superfluous given the contents of Article 6 of the SEA Protocol. Furthermore, the notion of 'public participation' is explicitly provided for next to 'consultation'. In the SEA Directive, 'consultations' include public participation (Article 6). Contrary to the definition in the SEA Directive, the SEA Protocol definition does not include the provision of information on the (final) decision on the plan or programme.

After a number of discussions, it was finally agreed that the term 'impact' defined and used by the Espoo Convention would be replaced by 'effect', which is used in the EU SEA Directive and was part of the first draft elements for the SEA Protocol. However, some delegations objected and favoured the term 'implications'. ${ }^{43}$ Finally and, due to the widening of 'environmental' concerns towards impacts on human health, the outcome was a definition of 'environmental, including health, effect'. This definition repeats almost all elements to be found in the SEA Directive (Annex I, f) and in the definition of 'impact' in the Espoo Convention. Nevertheless, one important issue from the latter has been omitted: effects on socio-economic conditions resulting from changes to environmental media. The SEA Protocol also includes the definition of 'the public' as defined

September 2002), Resolution 2, Annex, found at <http://daccess-ddsny.un.org/doc/UNDOC/GEN/N02/636/93/PDF/N0263693.pdf?Open Element>.

${ }^{41}$ E. Rehbinder, 'World Summit on Sustainable Development', 1 ELNI Review (2003), 2. See also S. Marsden, n. 29 above, at 97.

${ }^{42}$ In the course of the negotiations, the list of definitions became longer, including definitions of 'strategic decision' (and 'plans and programmes', 'policies', 'legal acts') and 'public health'. See Report of the Third Session (Orvieto, 21-23 November 2001) of the Ad hoc Working Group on the Protocol on Strategic Environmental Assessment (MP.EIA/AC.1/2001/8, 11 January 2002)

${ }^{43}$ Report of the Second Session (Geneva, 26-28 September 2001) of the Ad hoc Working Group on the Protocol on Strategic Environmental Assessment (MP.EIA/AC.1/2001/6, 6 November 2001), found at $<$ http://www.unece.org/env/eia/ahwg_sea2.html>. in the Aarhus Convention (Article 2, paragraph 4) but not the definition of 'the public concerned', although this term is being used in some provisions of the SEA Protocol. ${ }^{44}$

Article 3 contains a number of general provisions that are an adaptation of the general provisions in Article 3 of the Aarhus Convention. Article 3.2 of the SEA Protocol states: 'Each Party shall endeavour to ensure that officials and authorities assist and provide guidance to the public in matters covered by this Protocol.'45 This provision is clearly inspired by the Article 3.2 of the Aarhus Convention, ${ }^{46}$ which stipulates that: 'Each Party shall endeavour to ensure that officials and authorities assist and provide guidance to the public in seeking access to information, in facilitating participation in decision making and in seeking access to justice in environmental matters.

Article 4 of the SEA Protocol covers the field of application concerning plans and programmes. Discussion of this article was one of the core issues of the negotiations. The initial provision on the area of application in the first draft of the SEA Protocol was short but ambitious. It stated: 'The provisions of this Protocol shall apply at national, regional, local, transboundary and international levels, to strategic decisions at plan, programme, policy, regulatory and legislative level in key sectors.' 47 The final text of Article 4 is now restricted to plans and programmes, but more comprehensive. This article, as well as Article 5 on screening, reflects the major influence of the SEA Directive as the same approach was applied and the same structure was used in the Protocol.

The second paragraph of Article 4 provides for a mandatory SEA for plans and programmes in a number of sectors. ${ }^{48}$ These plans and programmes set the

${ }^{44}$ See, for example, SEA Protocol, n, 1 above, Articles 5(3), 6(3), $8(3), 8(4)$ and $8(5)$. See also the definition of 'the public concerned' in the Aarhus Convention, n. 32 above, Article 2(5).

${ }^{45}$ See SEA Protocol, n. 1 above, Article 3(2).

${ }^{46}$ Aarhus Convention, n. 32 above, Article 3(2) stipulates: 'Each Party shall endeavour to ensure that officials and authorities assist and provide guidance to the public in seeking access to information, in facilitating participation in decision making and in seeking access to justice in environmental matters.' Some particularities, such as the provision obliging Parties to promote education and awareness (Article 3(3) of the Aarhus Convention), have been omitted in the SEA Protocol - presumably due to the more technical character of the SEA Protocol compared to the more horizontal objectives of the Aarhus Convention.

${ }^{47}$ See Draft Elements for a Protocol on Strategic Environmental Assessment, n. 39 above, Article 5.

48 These sectors are agriculture, forestry, fisheries, energy, industry including mining, transport, regional development, waste management, water management, telecommunications, tourism, town and country planning or land use. The following 'sectors', which were mentioned in the original draft, were not kept: military training grounds, trade, nature conservation and modern biotechnology. See ibid. 
framework for future development consent for projects for which an EIA is required in accordance with international or national legislation. These projects are to be found in two annexes to the SEA Protocol. Annex I is identical to Appendix I of the Espoo Convention, which contains a list of major activities for which a transboundary EIA is mandatory. This Appendix was amended by Decision III/7 of the Third Meeting of the Parties to the Espoo Convention (Cavtat, 1-4 June 2004) in order to have almost identical lists in the UNECE and EU legislation.

Annex II of the SEA Protocol contains the projects mainly listed in Annex 2 of the EIA Directive. Annex 2 of the EIA Directive is the list of categories of projects for which EU Member States need to specify under which conditions an EIA may be required. As Annex II of the SEA Protocol, this has been transformed into a list of 90 project descriptions. Whereas for the SEA Directive the formal link to the EIA Directive in the relevant provision is obvious, this was not the case for the SEA Protocol given the different EIA systems and requirements in the UNECE Member States. In accordance with Articles 4(3) and 5(1) of the SEA Protocol, Parties can require a SEA for other plans and programmes. Article 4 contains similar requirements as the SEA Directive regarding plans and programmes which determine the use of small areas at local level or for minor modifications to plans and programmes. This particular screening opportunity concerns only the plans and programmes of the listed sectors. Compared to the sectors mentioned in the SEA Directive, the SEA Protocol has only added 'regional development' (which is only temporarily excluded in the SEA Directive, Article 3(9)) and 'mining' as part of the industry sector. Plans and programmes with respect to national defence, civil emergency, finances or budgets are excluded in both SEA instruments.

In general, Article 4 together with the two annexes provide guidance on the cases in which plans or programmes without a previous SEA might be considered as a possible breach of an international obligation by the 'competent' State.

Unlike the SEA Directive, the SEA Protocol contains a separate screening provision (Article 5). However, the screening methods provided for are the same as stipulated in Article 3(5) of the SEA Directive: case-bycase examination, specifying types of plans and programmes, or combining both approaches. Also, the screening criteria to be used for determining the likely significance of effects are similar (Annex III) and include the consultation of environmental and health authorities, as well as the publicity of the screening decision. With respect to the last issue, the SEA Protocol contains detailed requirements and precise wording. Active informing of the target public is not required, but at least some affirmative action is required as the information must be made publicly available 'by public notice or other appropriate means, such as electronic media'. ${ }^{49}$ Furthermore, Article 5(3) contains a non-binding provision on the participation of the public concerned ${ }^{50}$ in the screening process..$^{51}$

Scoping is the subject of Article 6 of the SEA Protocol. Parties are obliged to introduce a scoping arrangement. The SEA Directive has no separate scoping provision. The provision on the environmental report, however, contains one paragraph with respect to the consultation of environmental authorities in the scoping process, which reveals the assumption in the SEA Directive that a certain scoping approach should be available. The SEA Protocol reflects the need for a more elaborated approach that may include the opportunity for the public concerned to participate in a way that the scoping might be influenced. The language in paragraph 3 of this article is again non-binding and similar to the above-mentioned screening provision.

Article 7 of the SEA Protocol contains the provisions on the environmental report. Next to the obligation to prepare an environmental report when a plan is subject to a strategic environmental assessment, this Article contains elements of Articles 5(1) and 5(2) of the SEA Directive. Once again the 'Aarhus spirit' has made its way, as the environmental report has to contain 'reasonably required information' ${ }^{52}$ taking into account 'the interests of the public'. The wording of this provision is quite straightforward so one may wonder how 'unwilling' Parties shall transpose and implement Article 6(3) of the SEA Protocol as providing for public participation in the scoping stage of the SEA process seems to be rather fundamental in order to implement and fulfil the requirement of Article 7(2)(c).

Article 7(3) is a copy of the first part of Article 12(2) of the SEA Directive. It concerns a very general quality control obligation with regard to the environmental reports. During the negotiations, some attempts by the European Commission were made to include more detailed requirements, but these attempts were

\footnotetext{
${ }^{49}$ See J. Jendroska and S. Stec, n. 36 above, at 109.

50 See definition of 'public concerned' in Aarhus Convention, n. 32 above, Article 2(5).

${ }^{51}$ SEA Protocol, n. 1 above, Article 5(3) states: 'To the extent appropriate, each Party shall endeavour to provide opportunities for the participation of the public concerned in the screening of plans and programmes under this article.' The first draft of the Protocol included the following more stringent provision: 'The decision to subject to or to exempt from strategic environmental assessment a strategic decision or a particular type of strategic decision shall take into account comments by the public and by environmental and health authorities.'

${ }^{52}$ The required information is further specified in Annex IV, which is similar to the Annex I to the SEA Directive (Directive 2001/42/EC, n. 33 above) with the addition of 'transboundary effects'.
} 
unsuccessful. These were based on a proposal ${ }^{53}$ in the original draft, which was more comprehensive. ${ }^{54}$

A number of public participation requirements, which were the result of at times difficult discussions during the negotiations, are provided for in Article 8 of the SEA Protocol. The severe discussions were not surprising given the fact that the first paragraph of the public participation provision in the original draft of the SEA Protocol not only envisaged the strategic environmental assessment procedure, but also all 'procedures for making strategic decisions' for which a SEA should be required under the Protocol. Except for the first paragraph of Article 8, the other four paragraphs contain provisions similar to the ones in Article 6 of the SEA Directive. This is, of course, not surprising as both try to transpose Article 7 of the Aarhus Convention. ${ }^{55}$ This article refers to Article 6, paragraphs 3, 4 and 8, of this convention. In fact, Article 8(1) of the SEA Protocol is a duplication of Article 6(4) of the Aarhus Convention, except for replacing the verb 'provide for' by 'ensure': 'Each Party shall ensure early, timely and effective opportunities for public participation, when all options are open, in strategic environmental assessment for plans and programmes.'

The use of 'early' triggers the question of what is meant by early in strategic environmental assessment, especially given the additional requirement 'when all options are open'..$^{56}$ The above-mentioned definition of SEA focuses on the evaluation of likely effects. Anyone who is familiar with impact assessment is aware that a screening decision, whether to require a report or not, is based on a preliminary evaluation of likely significant

\footnotetext{
${ }^{53}$ The provision was Article 11 of the draft Protocol (see Draft Elements for a Protocol on Strategic Environmental Assessment, n. 39 above, Article 11), stating:

Each Party shall make the necessary arrangements to ensure that the quality of the strategic environmental assessment documentation as referred to in article 9 is appropriate for the decision, taking into account the comments on the quality of the documentation by environmental and health authorities and by the public.

${ }^{54}$ The quality control provision was introduced in the SEA Directive by an amendment from the European Parliament. See J. De Mulder, n. 33 above, at 15.

${ }^{55}$ For a critical review of the compatibility of the SEA Directive with Article 7 of the Aarhus Convention, see A. Mathiesen, 'Public Participation in Decision Making and Access to Justice in EC Environmental Law: The Case of Certain Plans and Programmes', 12:2 European Environmental Law Review (2003), 36, at 46.

${ }^{56}$ The use of the word 'early' in relation to the use of the general SEA notion can be compared to the use of 'early' in SEA Protocol (n. 1 above) Article 9(3), which states:
}

Each Party shall ensure that the authorities referred to in paragraph 1 are given, in an early, timely and effective manner, the opportunity to express their opinion on the draft plan or programme and the environmental report.

A similar phrasing has not been used in Article 8(4); thus, the use of 'early' has in Article 8(1) a very general, yet far-reaching meaning.

๑) 2012 Blackwell Publishing Ltd effects. According to my understanding, this means that the stringent wording of Article 8(1) does not give Parties much discretion with respect to the application of Article 5(3), as well as Article 6(3) of the SEA Protocol. Furthermore, the fact that Article 8(3) uses the words 'purposes of paragraphs 1 and 4' means that these purposes are obviously different. In particular, it could be argued that while the public participation referred to in paragraph 4 is identical to the public participation as required by the SEA Directive, Article(2) (which comes in the final stage of the SEA process - namely when the report is finished), the public participation referred to in paragraph 1 has to be situated earlier in the process.

The last paragraph of Article 8 requires the determination of detailed arrangements for informing the public and consulting the public concerned and refers to Annex V. This annex contains the elements that should be part of the information to be made public. The contents are similar to the information required by Articles 6(2)(d) and 6(2)(e) of the Aarhus Convention.

Article 9 of the SEA Protocol concerns consultation with environmental and health authorities. This article contains the same requirements as the ones provided for with respect to the consultation of 'environmental' authorities in Article 6 of the SEA Directive. Given the wider approach of the SEA Protocol to include healthrelated impacts, it is not surprising that the health authorities are explicitly mentioned.

Article 11 of the SEA Protocol combines requirements regarding the contents of the decision about the plan or programme with provisions on the publicity of the decision. The SEA Directive deals with these issues in two separate provisions (Articles 8 and 9 of the SEA Directive). There is also a difference between Article 11(1) of the SEA Protocol ${ }^{57}$ and Article 8 of the SEA Directive. The latter requires that the environmental reports and comments on it, as well as results of transboundary consultations, must 'be taken into account during the preparation of the plan or programme and before its adoption'. Article 11(2) of the SEA Protocol requires the same as Article 9(1) of the SEA Directive, but does not require that monitoring measures should be made public.

Article 12 contains a monitoring provision similar to Article 10(1) of the SEA Directive and stipulates in

57 SEA Protocol, ibid., Article 11(1) states:

Each Party shall ensure that when a plan or programme is adopted due account is taken of:

(a) The conclusions of the environmental report;

(b) The measures to prevent, reduce or mitigate the adverse effects identified in the environmental report; and

(c) The comments received in accordance with articles 8 to 10 . 
paragraph 2 that monitoring results shall be made available to the consulted authorities and the public..$^{58}$ The SEA Directive does not define the term 'monitoring', but the Commission's SEA Guidance does. It states: 'Monitoring can however, be generally described as an activity of following the development of the parameters of concern in magnitude, time and space. In the context of Article 10 and its references to unforeseen adverse effects and remedial action, monitoring may also be a means of verifying the information in the environmental report.'59

Article 10 does not contain any technical requirements about the methods, which are to be used for monitoring the significant environmental effects. The objective of Article 10, which is to find out whether the assumptions made in the environmental assessment correspond with the environmental effects that occur when the plan or programme is implemented and to identify at an early stage unforeseen adverse effects resulting from the implementation of the plan or programme, may give some orientation in this respect. Furthermore, it follows from Article 10(2) and the potential revision of the plan or programme which is implicitly addressed by the words 'remedial action', that Article 10 creates an obligation which, although coming into effect after the environmental assessment and the adoption of the plan or programme, may be integrated in the regular planning cycle where appropriate. It is not necessarily required to establish a separate procedural step for the purpose of monitoring. Monitoring may coincide, for example, with the regular revision of a plan or programme.

Article 13 deals with another aspect that belonged originally to the draft provision on the area of application namely policies and legislation. Already during the first meeting of the ad hoc drafting Working Group, it became clear that the requirements regarding SEA for policies and legislation would be formulated in a less stringent way. It is even undeniable that quite a number of EU Member States would have preferred to see nothing on policies and legislation in the SEA Protocol. But it was difficult to negate Articles 7 and 8 of the Aarhus Convention. At a certain moment, two competing proposals ${ }^{60}$ were the subject of the negotiations. The

${ }^{58} \mathrm{R}$. Bart and A. Fuder, Impel-project - Implementing Article 10 of the SEA-Directive 2001/42/EC (Oeko-Institut, Environmental Law Division, November 2002).

${ }^{59}$ European Commission, Implementation of Directive 2001/42 on the assessment of the effects of certain plans and programmes on the environment (European Commission, 2004), found at <http:// ec.europa.eu/environment/eia/pdf/030923_sea_guidance.pdfs.

${ }^{60}$ Further updated version of the substantive provisions of a protocol on strategic environmental assessment, prepared by the secretariat in consultation with the Bureau as incorporated in the Report of the Fifth Session of the Ad hoc Working Group on the Protocol on Strategic Environmental Assessment (MP.EIA/AC.1/2002/5, 18 July 2002), found at <http://www.unece.org/env/eia/ahwg_sea5.html>. This document contains two alternatives for Article 8, one using binding language, and the other using non-binding wording: outcome of the discussions reflects these views in a fairly balanced way. ${ }^{61}$

Compared to the initial draft ${ }^{62}$ of the SEA Protocol, as presented during the first meeting, the outcome of the negotiations agreed during the last round of negotiations in Geneva (January 2003) is a text that was trimmed and lacks some essential elements to consider it a major step forward compared to the SEA Directive. Despite this observation that more progress could have been made (e.g., on the approach regarding health effects), some commentators still consider the SEA

Alternative 1

1. Each Party shall ensure that environmental, including health, concerns are considered and appropriately integrated in preparing any of its proposed policies and legal acts that may have significant effects on the environment.

2. Each Party shall determine the practical arrangements for the application of paragraph 1 within the framework of its national legislation.

\section{Alternative 2}

To the extent appropriate, the Parties shall endeavour to apply the principles of this Protocol (...) to legal acts and policies which are likely to have significant effects on the environment.

Both proposals contained an identical 'escape' provision, stating:

Each Party may decide not to apply the provision of this article. Such a Party shall, upon ratification of this Protocol, inform the other Parties about this decision.

${ }^{61}$ Furthermore, the text no longer contains the possibility for a Party to decide not to apply this article. As this article really offers 'something more', in comparison to the SEA Directive, it is worthwhile to give the full text:

1. Each Party shall endeavour to ensure that environmental, including health, concerns are considered and integrated to the extent appropriate, in preparing any of its proposed policies and legislation that are likely to have significant effects on the environment, including health.

2. In applying paragraph 1 , each Party shall consider the appropriate principles and elements of this Protocol.

3. Each Party shall determine, where appropriate, the practical arrangements for undertaking the consideration and integration of environmental, including health, concerns in accordance with paragraph 1 , taking into account the need for transparency in decision making

4. Each Party shall report to the Meeting of the Parties to the Convention serving as the Meeting of the Parties to this Protocol on its application of this article.

The wording of the last paragraph is clearly intended to push parties towards the implementation of this Article as this reporting provision is in addition to the 'general' reporting provision in Article 14, paragraph 7, which states: 'Each Party shall, at intervals to be determined by the Meeting of the Parties to the Convention serving as the Meeting of the Parties to this Protocol, report to the Meeting of the Parties to the Convention serving as the Meeting of the Parties to the Protocol on measures that it has taken to implement the Protocol.' ${ }^{62}$ See Draft Elements for a Protocol on Strategic Environmental Assessment, n. 39 above. 
Protocol as a valuable addition to the existing family of multilateral environmental agreements. ${ }^{63}$

\section{ENTRY INTO FORCE}

The SEA Protocol entered into force on 11 July 2010, following Estonia's ratification, which was deposited with the United Nations Secretary-General on 12 April 2010. In becoming a Party to the SEA Protocol, Estonia joined eleven other EU Member States, as well as the EU itself. As of 14 November 2011, there are 23 Parties to the SEA Protocol. The SEA Protocol, though negotiated by UNECE Member States and signed by European Ministers of Environment, is open to all UN Member States, upon approval by the Meeting of the Parties to the Protocol.

The First Meeting of the Parties to the Convention on Environmental Impact Assessment in a Transboundary Context serving as the Meeting of the Parties to the Protocol on Strategic Environmental Assessment (MOP/MOP, Geneva, 20-23 June 2011) adopted Decision I/8 providing for the procedures for accession and approval of non-UNECE members accordingly. ${ }^{64}$ At this meeting, Decision I/6 was adopted, which extends the compliance mechanism under the Espoo Convention, operated by its Implementation Committee, to review States' compliance with the SEA Protocol. The outcomes (ten decisions) of this first MOP/MOP are not very ambitious. ${ }^{65}$ The workplan adopted by Decision I/9 (also Decision V/9 of the MOP) includes, inter alia, a number of thematic or (sub)regional initiatives. Also cooperation with the Aarhus Convention is continued through an initiative for a joint workshop on public participation in strategic decision making (Decision $\mathrm{I} / 4)$.

\section{GUIDANCE TOOLS}

In October 2007 the UNECE published a paper entitled 'Applying the Protocol on SEA'. This paper explains the concepts of SEA and the Protocol. It also describes the benefits and costs of SEA, and outlines the resources available to develop capacity and assist in the application of the Protocol - notably through a Resource Manual. The paper emphasizes that SEA aims to strengthen governance. It states:

SEA increases the overall transparency of strategic decisionmaking and allows the early consideration of the opinions of key stakeholders in the plan- or programme-making process. Properly undertaken and accountable SEA

${ }^{63}$ See J. Jendroska and S. Stec, n. 36 above, at 110.

${ }^{64}$ UNECE, Report of the Meeting of the Parties on Its Fifth Session (ECE/MP.EIA/15, 16 August 2011), found at <http://www.unece.org/ fileadmin/DAM/env/documents/2011/eia/ece.mp.eia.15.e.pdfs.

${ }^{65}$ It is too early to develop expectations about further legal developments. See S. Marsden, n. 29 above, at 109. enhances the credibility of plans and programmes. It may mobilize public support for implementation - a plan or programme may be more effective when the values, views, opinions and knowledge of the public have become part of the decision-making process. ${ }^{66}$

The Resource Manual to Support Application of the UNECE Protocol on SEA (April 2007, revised February 2011) ${ }^{67}$ addresses all SEA stakeholders for it states that it is expected to be used by, first, those who want to learn about the Protocol and the theory of its application, including government and other officials working on the application of the Protocol, practitioners carrying out SEAs and stakeholders wishing to participate in the SEA process, and second, those who want to advise and train others on the Protocol's requirements and the application of SEA. ${ }^{68}$

As the above overview of substantive provisions of the SEA Protocol has shown, the Protocol contains provisions which require or imply a number of actions by public authorities. These include having a role and responsibility (including liabilities) in the following areas:

- assistance and providing guidance to the public (Article 3(2));

- screening (consultation of authorities, Article 5(2));

- scoping (consultation of authorities, Article 6(2));

- quality assurance of the environmental report (Article 7(3));

- providing for public participation opportunities (Article 8);

- consultations (of authorities about the environmental report and plan or programme, Article 9) including transboundary consultations (Article 10); and

- using the environmental report for the decision and informing authorities about the decision (Article 11) and about the monitoring results (Article 12).

Authorities as actors in the public sector play crucial roles in the settings of strategic environmental assessment. ${ }^{69}$ In the SEA context, authorities are involved in handling several public services, as service producer (e.g., scoping and other decisions), as service provider (e.g., process management) and as service consumer (e.g., use of the report). These perspectives are,

${ }^{66}$ UNECE, Applying the Protocol on SEA: Application of the UNECE Protocol on Strategic Environmental Assessment (UNECE, 2007), found at <http://live.unece.org/fileadmin/DAM/env/eia/documents/ pamphlets/Pamphlet\%20-\%20SEA\%20Protocol\%20Implementation. pdf>.

${ }^{67}$ UNECE, Resource Manual to Support Application of the UNECE Protocol on SEA (ECE/MP-EIA/17, December 2011), found at <http:// www.unece. org/index. php?id=27379>; the previous version was available at: <http://live.unece.org/fileadmin/DAM/env/eia/sea_manual/ documents/SEAmanualDraftFinalApril2007notags.pdfs.

${ }^{68} \mathrm{Ibid}$., at 3.

${ }^{69}$ M. van Genugten, 'Comparing Impacts of Modes of Governance', in P. Laegreid and K. Verhoest (eds), n. 11 above, 177, at 180. 
however, not fully elaborated in the SEA Protocol Resource Manual, which offers only some guidance from a dominantly SEA methodology perspective. ${ }^{70}$ The new Workplan as adopted by the Espoo parties announces (technical) maintenance and the elaboration of a simplified version of the Resource Manual, but no specific substantive improvements. ${ }^{71}$

\section{SEA AND QUALITY CONCERNS}

\section{QUALITY ASSURANCE RULES}

Article 7(3) of the SEA Protocol stipulates that: 'Each Party shall ensure that environmental reports are of sufficient quality to meet the requirements of this Protocol. ${ }^{72}$ This brief provision, as well as Article 12 of the SEA Directive, ${ }^{73}$ suggests that limited attention is traditionally paid to quality requirements for SEA processes. The Commission's Guidance on the implementation of the SEA Directive clarifies this, stating:

The Directive does not elaborate what is sufficient quality. But since the SEA process and environmental report are both defined by the Directive, a correct transposition and proper application of its provisions, both in content and procedure would appear to meet the requirement for sufficient quality. The procedural and substantive requirements of the Directive, if properly implemented and applied, may be envisaged as a 'minimum standard' for ensuring the quality of environmental reports. Member States may decide for themselves whether to establish additional measures and, if so, what these should be. ${ }^{74}$

${ }^{70}$ B. Noble and K. Storey, 'Towards a Structured Approach to Strategic Environmental Assessment', 3:4 J. Environmental Assessment Policy and Management (December 2001), 483, at 503, who state:

A structured methodological SEA framework is required if SEA is to advance in application and effectiveness.... [H]owever attention needs to be directed towards the political and administrative barriers to formal SEA. Without the appropriate political and administrative triggers for SEA, and without the necessary institutional capacity for its implementation, even the most effective SEA methodologies will have little significance for PPP processes.

${ }^{71}$ Report of the Meeting of the Parties to the Convention on Environmental Impact Assessment in a Transboundary Context on Its Fifth Session, Geneva, 20-23 June 2011 (ECE/MP.EIA/15, 16 August 2011), found at <http://www.unece.org/env/eia/meetings/ mop_5.html>.

${ }^{72}$ See SEA Protocol, n. 1 above, Article 7(3).

${ }^{73}$ Contrary to the EIA Directive n. 38 above, which is silent in this respect, the SEA Directive (n. 34 above), Article 12(2) requires that: 'Member States shall ensure that environmental reports are of a sufficient quality to meet the requirements of this Directive and shall communicate to the Commission any measures they take concerning the quality of these reports.' The application of this Article has not been reviewed in the Report on the application and effectiveness of the Directive on Strategic Environmental Assessment (Directive 2001/42/EC), COM (2009) 469 final.

${ }^{74}$ Implementation of Directive 2001/42 on the assessment of the effects of certain plans and programmes on the environment
The SEA Protocol Resource Manual includes a brief chapter on the quality of environmental reports ${ }^{75}$ including a quality assurance checklist (at Table A4.4). The Resource Manual also contains some additional, but rather questionable, phrases about the possible institutional setting for quality assurance. For example, it states:

Responsibility for assuring quality will depend on the institutional arrangements in a country. The same authority that prepared the environmental report might also be responsible for assuring its quality. The body responsible for preparing guidelines might also take on a role of quality control, or an independent commission might be set up or an existing audit commission have its mandate extended. ${ }^{76}$

Discussions on quality in SEA have been primarily focused on the quality of the reports. A good report is usually an effective report: one that influences the final decision making on the proposed activity. ${ }^{77}$ In order to obtain good quality output, procedures have been developed that include the major SEA stages (screening, scoping, consultation, review). ${ }^{78}$ SEA procedures are prescribed in laws and regulations. As a product of such a procedure, the quality of a report or statement is likely to reflect the quality of the applied procedure in a formal way, but also more informal features such as common administrative practices. So when addressing the quality issue of SEA, one has to look beyond the legal context. ${ }^{79}$

A good quality SEA process informs plan- and programme-makers, decision-makers and the affected public on the sustainability of strategic decisions, facilitates the search for the best alternatives and ensures a democratic decision-making process. This enhances the credibility of decisions and leads to more cost- and time-effective EIA at the project level. The International Association for Impact Assessment (IAIA) has developed performance criteria for SEA. ${ }^{80}$ Based on these criteria, a good quality SEA process is: integrated, sustainability-led, focused, accountable, participative, iterative and influential.

(European Commission, 2004), at 32, found at <http://ec.europa.eu/ environment/eia/pdf/030923_sea_guidance.pdf>.

75 See UNECE, n. 67 above.

${ }^{76}$ Ibid., at 76. Table A4.4 (at 77) is copied from the United Kingdom. ${ }^{77}$ K. Fuller, 'Quality and Quality Control in Environmental Impact Assessment', in J. Petts (ed)., Handbook of Environmental Impact Assessment, Vol. 2 (Blackwell Science, 1999), 55.

${ }^{78}$ C. Wood, Environmental Impact Assessment: A Comparative Review (Longman, 1995), at 5.

${ }^{79}$ See R. Therivel, n. 20 above, at 185-94.

80 International Association for Impact Assessment (IAIA), Strategic Environmental Assessment Performance Criteria, Special Publication Series 1 (January 2002), found at <http://www.iaia.org/ publicdocuments/special-publications/sp1.pdf>. See also T. Fischer, 'Strategic Environmental Assessment Performance Criteria: The Same Requirements for Every Assessment?', 4:1 J. Environmental Assessment Policy and Management (March 2002), 83. 
Reviewing each of these criteria, an integrated SEA process ensures an appropriate environmental assessment of all strategic decisions relevant for the achievement of sustainable development; addresses the inter-relationships of biophysical, social and economic aspects; and is tiered to policies in relevant sectors and (transboundary) regions and, where appropriate, to project EIA and decision making. A sustainability-led SEA process facilitates the identification of development options and alternative proposals that are more sustainable. A focused SEA process provides sufficient, reliable and usable information for development planning and decision making, concentrates on key issues of sustainable development, is customized to the characteristics of the decision-making process, and is costand time-effective. An accountable SEA process is the responsibility of the leading agencies for the strategic decision to be taken, is carried out with professionalism, rigour, fairness, impartiality and balance, is subject to independent checks and verification, and documents and justifies how sustainability issues were taken into account in decision making. A participative SEA process informs and involves interested and affected public and government bodies throughout the decision-making process, explicitly addresses their inputs and concerns in documentation and decision making, has a clear, easily understood information requirement, whilst ensuring sufficient access to all relevant information. An iterative SEA process ensures availability of the assessment results early enough to influence the decision-making process and inspire future planning, and provides sufficient information on the actual impacts of implementing a strategic decision to judge whether this decision should be amended and to provide a basis for future decisions. The 'influence' criterion concerns the 'usability' or benefits of the SEA process.

The IAIA performance criteria illustrate the focus on analytical strategic environmental assessment (ANSEA) as elaborated by its ANSEA Research Project. It involves a shift from an analysis of the environmental consequences of a decision to an analysis of the decision-making process. The focus is on the priorities, issues and values that govern decision making. The aim is to ensure integration of environmental objectives and values into the decision-making process and to provide a complementary and decision-centred approach to the assessment of policies, programmes and plans.

The ANSEA Project identified specific procedural criteria: comprehensiveness, timeliness, transparency, participation, credibility. The approach is based on the idea that environmental assessment must turn to an assessment centred on the quality and consistency of a decision-making process against a set of environmentally relevant procedural criteria. ${ }^{81}$ Rotmans and Van

\footnotetext{
${ }^{81}$ See M. Nilsson and R. Jiliberto, n. 22 above, at 38.
}

Asselt distinguish three types of quality criteria for assessing impact assessments: analytical, methodological and usability. ${ }^{82}$ Whilst the first two are necessary to evaluate the internal quality, the latter category addresses the external quality. The seven core elements of the usability criteria are: the value of the problem definition; legitimacy; transparency; disciplinary benefit; societal benefit; effectiveness; and timeliness.

\section{QUALITY CONCERNS AND INTEGRATED ASSESSMENTS}

More integration of assessments and decision making may address the lack of efficiency and effectiveness of current (environmental) assessment arrangements. ${ }^{8_{3}}$ One of the challenges is to overcome unwillingness to cooperate or 'negative coordination'. ${ }^{84}$ But integrated assessments or integration of assessments cover a range of issues, as Scrase and Sheate illustrate in their exploration based on the various definitions of the term 'integration' ${ }^{85}$ Sustainable impact assessments (SIA), ${ }^{86}$ sustainability assessments and appraisals ${ }^{87}$ are examples of integrated assessments and have been developed and applied in order to inform policy makers

82 J. Rotmans and M.B.A. van Asselt, 'Integrated Assessment: Current Practices and Challenges for the Future', in H. Abaza and A. Baranzini, n. 3 above, at 93

${ }^{83}$ B. Dalal-Clayton and B. Sadler (n. 10 above, at 369) mention three types of integration: vertical, horizontal and integration of assessments into decision-making. See also United Nations Development Programme (UNDP), Mapping of ex-ante Policy Impact Assessment Experiences and Tools in Europe (UNDP, September 2007), found at $<$ http://europeandcis.undp.org/home/show/4D531880-F203-1EE9B16CA90EB5DEFCD3>.

${ }^{84}$ See S. Nooteboom and G. Teisman, 'Sustainable Development: Impact Assessment in the Age of Networking', 5:3 J. Environmental Policy and Planning (October 2003), 288.

85 J.I. Scrase and W. Sheate, 'Integration and Integrated Approaches to Assessment: What do They Mean for the Environment?', 4:4 J. Environmental Policy and Planning (October 2002), at 277.

${ }^{86}$ European Commission, DG Trade, Handbook for Trade Sustainability Impact Assessment (EC, March 2006), found at <http:// trade.ec.europa.eu/doclib/docs/2006/march/tradoc_127974.pdf>. On the OECD work concerning sustainability assessments, see OECD, Guidance on Sustainability Impact Assessment (OECD, 2010), found at <http://www.oecd.org/dataoecd/45/37/46530443.pdf $>$.

87 Two broad forms of sustainability assessment can be distinguished that reflect slightly different origins. In parts of Western Europe, sustainability assessment follows an SEA model with a planning focus - an example being the well-established sustainability appraisal process in the United Kingdom that applies to land-use plans. In jurisdictions where development is driven more by major infrastructure projects than by planning, such as Canada and Western Australia, sustainability assessment follows a model more closely related to project-level EIA. On sustainability appraisal, see Office of the Deputy Prime Minister, Sustainability Appraisal of Regional Spatial Strategies and Local Development Documents. Guidance for Regional Planning Bodies and Local Planning Authorities (Office of the Deputy Prime Minister, 2005), found at <http://www.communities. gov.uk/publications/planningandbuilding/sustainabilityappraisal>. See also N. Mahida, 'Strategic Environmental Assessment and Sustainability Appraisal: The Story of the Chicken and the Egg?', Conference Paper, SEA Implementation and Practice: Making an Impact? (21-23 
and stakeholders about potential impacts on sustainable development goals. SIAs - widely regarded as the next generation of SEA - treat economic, environmental and social impacts equally, while SEA has a greater focus on environmental aspects. ${ }^{88}$ This 'equal treatment' or horizontal integration, however, is widely distrusted, especially by environmental assessment promoters. Scrase and Sheate state that:

Integration, therefore, far from encouraging sustainable development, may be merely promoting the prevailing economically driven paradigm. Perhaps it is the target of integration that is fundamentally wrong, when what is really needed is more akin to a paradigm shift to a perspective that more actively recognizes and promotes the environmental imperative underlying sustainable development. ${ }^{89}$

Others have a more positive message. Nooteboom and Teisman argue that:

In any case, within a more sustainable political culture, a need will automatically emerge for information about sustainability impacts. Then, at strategic level, Impact Assessment could develop as a module to provide that information quickly within the dynamics of the decision-making process. ${ }^{90}$

These opinions reflect (dis)belief about, inter alia, the quality of the assessment processes - an issue which was central in a recent European Court of Auditors' Report about the Impact Assessment practices of the European Commission..$^{91}$ According to De Smedt, this

September 2011, Prague), found at <https://www.iaia.org/Special Meetings/prague11/proceedings/papers/SEA\%20\&SA_Mahida_21\% 20Sept\%202011.pdfs.

${ }^{88}$ OECD, 'Report on the Workshop on Sustainability Assessment Methodologies', in OECD, Conducting Sustainability Assessments (OECD, 11 June 2008), found at <http://www.oecd.org/dataoecd/36/ 60/40012580.pdf > and <http://www.oecd-ilibrary.org/environment/ conducting-sustainability-assessments_9789264047266-en>.

${ }^{89}$ See J.I. Scrase and W. Sheate, n. 86 above, at 291; and J. Holder, 'Prospects for EIA', in J. Holder and D. McGillivray, n. 18 above, at 267.

${ }^{90}$ See S. Nooteboom and G. Teisman, n. 84 above, at 307; see also G. Berger and R. Steuer, 'Horizontal Policy Integration and Sustainable Development: Conceptual Remarks and Governance Examples', ESDN Quarterly Report (June 2009), 1, at 8, who state: 'Generally, horizontal policy integration is one of the major objectives of sustainability impact assessments.'

${ }^{91}$ How opinions may differ is revealed by the evaluation by the European Court of Auditors of the European Commission's Impact Assessment practice. See European Court of Auditors, Impact Assessments in the EU Institutions: Do They Support Decisionmaking?', Special Report 3 (European Court of Auditors, 2010), at 36, which states: 'The Court's analysis showed that, in practice, the Commission's IA work was asymmetric between the three pillars and between costs and benefits (see Figure 9). This reflects the fact that not all types of impacts are equally relevant for any particular initiative. According to the survey of the Council WPs, a majority of respondents thought that there was an appropriate balance between the economic, environment and social impacts of the different policy options (see Figure 10).' integrated European Impact Assessment system $^{92}$ needs specific initiatives to shape the collaboration between science and policy as research outcomes do not fully reach policy-makers. ${ }^{93}$ Contrary to this analysis, but looking specifically at SEA practice, Nitz and Brown conclude that SEA needs to focus on policy outcomes rather than solely on the scientific rigour of the environmental assessment. ${ }^{94}$ Runhaar has drawn attention to the content of the policy discourse. A focus on this discourse yields additional insights on how SEA and its outcomes are perceived and what arguments are found to incorporate elements of SEA in decision making. ${ }^{95}$

\section{QUALITY MANAGEMENT}

Quality management systems are internal control approaches used at the organizational (or micro-) level. ${ }^{96}$ However, quality reviews are also part of the SEA methodology. ${ }^{97}$ The UNECE Resource Manual and SEA literature does not reveal much interest from the SEA field for linkages with existing public management quality or performance approaches, like the Common Assessment Framework (CAF) or the European Foundation for Quality Management (EFQM). The EFQM

92 The Impact Assessment system as applied by the European Commission was introduced after the adoption of the White Paper on Governance of the European Commission. See European Commission, 'European governance: a white paper', COM (2001) 428 final. The White Paper listed the following as principles of good governance: openness, participation, accountability, effectiveness, coherence. The White Paper stated that the need for coherence in the union is increasing - the range of tasks has grown; enlargement will increase diversity; and challenges such as climate and demographic change across the boundaries of the sectoral policies on which the union has been built. For an elaborated analysis, see A. Meuwese, Impact Assessment in EU Lawmaking (Kluwer Law International, 2008). See also C. Radaelli, L. Allio, A. Renda and L. Schrefler, How to Learn from the International Experience: Impact Assessment in the Netherlands (Centre for European Governance, University of Exeter, 2 March 2010), found at <http://www. eerstekamer.nl/behandeling/20100527/how_to_learn_from_the/f=/ vifklgll6miz.pdf>. Concerning the quality assurance of the EU's impact assessment system, see J. Koniecki, 'The European Commission's Impact Assessment System: How to Ensure Good Quality?, presentation at Evaluating Policies for Sustainable Development Seminar (Brussels, 16 June 2009), found at <http://ecologic.eu/soef/ epos/download/Koniecki_Jakub.pdf $>$.

${ }^{93}$ P. De Smedt, 'The Use of Impact Assessment Tools to Support Sustainable Policy Objectives in Europe', 15:4 Ecology and Society (2010), at 30, found at <http://www.ecologyandsociety.org/vol15/iss4/ art30/>.

${ }^{94}$ T. Nitz and A.L. Brown, 'SEA Must Learn How Policy Making Works', 3:4 J. Environmental Assessment Policy and Management (September 2001), 329, at 340.

${ }^{95} \mathrm{H}$. Rungaar, 'Putting SEA in Context: A Discourse Perspective on How SEA Contributes to Decision-making', 29:3 Environmental Impact Assessment Review (2009), 200, at 208.

${ }^{96} \mathrm{~J}$. Spanhove and K. Verhoest, 'Analyzing Government Governance at Different Levels: Developing a Normative and Analytical Framework based on Principles, Processes, Instruments and Cycles', paper presented at the European Group for Public Administration Conference (Madrid, 19-22 September 2007), at 17.

${ }^{97}$ See B. Dalal-Clayton and B. Sadler, n. 10 above, at 367. 
Excellence Model is a management framework used by over 30,000 organizations in Europe and beyond. Often used as a diagnostic tool, it takes a holistic view to enable organizations, regardless of size or sector to: assess where they are, helping them to understand their key strengths and potential gaps in performance across nine criteria; provide a common vocabulary and way of thinking about the organization that facilitates the effective communication of ideas, both within and outside the organization; and integrate existing and planned initiatives, removing duplication and identifying gaps.

The EFQM Excellence Model is used as a basis for self-assessment - an exercise in which an organization grades itself against the Model's nine criteria. One of these nine fundamental concepts of the EFQM Excellence Model is 'Taking Responsibility for a Sustainable Future':

Excellent organisations embed within their culture an ethical mindset, clear values and the highest standards of organisational behaviour, all of which enable them to strive for economic, social and ecological sustainability. ${ }^{98}$

This illustrates the growing tendency or linkage of sustainable development considerations or instruments to 'classical' public management instruments.

CAF is a total quality management (TQM) tool specifically designed for the development of TQM in public sector organizations starting with a self-assessment of their organizational performance. ${ }^{99} \mathrm{CAF}$ has four main purposes: to introduce public administrations to the principles of TQM and gradually guide them, through the use and understanding of self-assessment, from the current 'Plan-Do' sequence of activities to a full fledged 'Plan-Do-Check-Act (PCDA)' cycle; to facilitate the selfassessment of a public organization in order to arrive at a diagnosis and improvement actions; to act as a bridge across the various models used in quality management; and to facilitate bench-learning between public sector organizations.

Since the launch of the first version in 2000 and revised versions in 2002 and 2006, more than 2,000 organizations in many European countries have implemented the CAF Excellence Model, but until recently there were

\footnotetext{
${ }^{98}$ See M. Fischer, Introducing the EFQM Excellence Model (EFQM, 2011), found at $<$ http://www.efqm.org/en/Home/TheEFQMExcellence Model/FundamentalConcepts/tabid/169/Default.aspx>.

99 'Total Quality Management' has been described as a new way of thinking about the management of organizations, a comprehensive way to improve total organization performance and quality, an alternative to 'management by control', and as a paradigm shift. See B. Spencer, 'Models of Organization and Total Quality Management: A Comparison and Critical Evaluation', 19:3 Academy of Management Review (1994), 446, at 446. See also M. Baracki, 'The Rhetoric and Reality of Total Quality Management', 43:3 Administrative Science Quarterly (September 1998), 602.
}

no indications for broadening it towards sustainability criteria. ${ }^{100}$ Under the Spanish EU Presidency in 2010, a study was conducted in the EU Public Administration Network (EUPAN). ${ }^{101}$ It recommended a 'light' Sustainability Performance Framework for Public Administration suitable for internal assessment and external reporting. This instrument should be capable of mainstreaming sustainability into the performance management system of any public agency and should also be compatible for use alongside CAF and other management models. ${ }^{102}$ The Report states that sustainable development may be targeted at different levels when applied to the public sector: sustainability of organizational operations; sustainability of public policies and services; and sustainability of the impact on all stakeholders. As is the case with any performance measurement system, existing sustainability measurement frameworks are conceived to serve one or more purposes, such as: mainstreaming sustainability; external reporting (usually for accountability purposes); benchmarking (usually either for accountability or for learning purposes); learning and innovation; and building trust and accountability with external stakeholders.

The EUPAN project referred also to a Supplement of (Environmental) Sustainability for the CAF framework being applied in Finland..$^{103}$ The supplement contains a checklist of items on sustainable development and is voluntarily applied by those organizations that need extra guidance to measure sustainability. This EUPAN Report provides an outline for a flexible European Sustainability Performance Framework. However, no follow-up activities have taken place over the past three EU Presidencies. Under the Polish Presidency an evaluation report was published about the use of CAF

100 See P. Staes et al., Five Years of CAF 2006: From Adolescence to Maturity - What Next? A Study on the Use, the Support and the Future of the Common Assessment Framework (EIPA, October 2011), found at <http://www.eupan.eu/files/repository/20111004115 359_CAFStudy2011_ResearchReport.pdf>.

101 EUPAN is an informal network of Directors General responsible for Public Administrations in EU Member States and European Commission. EUPAN aims to improve the performance, competitiveness and quality of European public administrations by developing new tools and methods based on the exchange of views, experiences and good practices among EU Member States, the European Commission and observer countries, in the field of central public administration. EUPAN works in different areas (human resources, innovation, quality, e-government) and with different actors in order to support efficiency and customer orientation in European public services. The Network is organized into three levels: political (Ministers and the Commissioner responsible for Public Administration), administrative (Directors General of each Member State) and technical (Working Groups).

${ }^{102}$ E. Loffler and S. Parrado, 'Towards Sustainable Public Administration', EUPAN Report, National Agency for the Evaluation of Public Policies and Quality of Services, Madrid (EUPAN, June 2010).

103 C. Hidalgo, 'Towards Sustainable Public Administration: The Contribution of the Spanish Presidency of the Innovative Public Services Group of EUPAN' (EUPAN, October 2010), at 11, found at <http:// www.wu.ac.at/inst/fsnu/brussels/papers/hidalgo.pdf>. 
2006. ${ }^{104}$ This report reveals that sustainability is one of the major new themes that needs further attention and elaboration: 'Sustainability, transparency and ethics should be put forward more as well as the principles of excellence in corporate social responsibility, partnerships and innovation, and creativity. ${ }^{105}$

\section{SOME FINAL OBSERVATIONS}

The SEA Protocol offers a framework for guiding decision making about future strategic actions by public authorities. Considerations about the impacts of these actions for the sustainable development of all stakeholders and future generations should be central in such a decision-making process. ${ }^{106}$ SEA should enhance evidence-based policy making as advocated under NPM in the quest for efficiency and effectiveness. ${ }^{107}$ SEA may also address 'substantive' or (negative) qualitative indirect NPM impacts that become visible in impact assessment practices. ${ }^{108}$ SEA struggles with challenges to address the wide range of public values and interests at stake as public administration systems become structurally and culturally more complex. ${ }^{109}$ To address these struggles may require the development of a new methodological approach. ${ }^{110}$ In this regard, SEA can contribute to the success of collaborative governance processes. ${ }^{111}$ Whether the use of quality management approaches will lead to any improvement is, however, questionable. As noted by Verhoest et al.: '[T]he introduction of managerial tools (and other innovations) by

\footnotetext{
104 P. Staes, et al., n. 100 above.

${ }^{105}$ Ibid., at 103.

${ }^{106}$ A. Weaver et al., 'Contributing to Sustainability as an Environmental Impact Assessment Practitioner', 26:2 Impact Assessment and Project Appraisal (2008), 91, at 97, who states: 'Practitioners, whether regulators, proponents or consultants, are environmental professionals and have an implicit responsibility to work towards a sustainable future. In a busy practice and with the demands of procedural and financial imperatives, it can become easy to slip into a "box ticking" approach.'

${ }^{107}$ See J. O'Flynn, n. 17 above, at 363.

${ }^{108}$ B.C. Karkkainen, 'NEPA and the Curious Evolution of Environmental Impact Assessment in the United States', in J. Holder and D. McGillivray, n. 18 above, at 61, who states: 'Some argue for increased emphasis on strategic environmental assessment at higher levels of decision-making, rather than the project-specific approach to impact assessment typically taken by agencies. Some call for stronger centralized data collection and supervisory review over the highly decentralized and possibly non-uniform NEPA compliance practices of federal agencies.'

${ }^{109}$ See T. Christensen and P. Laegreid, n. 11 above, at 259.

${ }^{110}$ M. Radej, F. Golobic and M. Cernic Istenic, 'Beyond "New Public Management" Doctrine in Policy Impact Evaluation', Working Paper 1 (Slovenian Evaluation Society, April 2010).

${ }^{111}$ A. Van Buuren and S. Nooteboom, 'The Success of SEA in the Dutch Planning Practice: How Formal Assessments can Contribute to Collaborative Governance', 30:2 Environmental Impact Assessment Review (2010), 127, at 134 ..
}

public sector organizations has more a symbolic function in order to strengthen their social legitimacy. ${ }^{112}$

This observation raises the question of how symbolic the SEA instrument might be as part of the (so-called) 'rational' policy cycle. As Everett states: '[T]he policy cycle is not a substitute for the actual making of decisions but an administrative and bureaucratic mechanism for effectively setting in place a process once the difficult decisions have been made. ${ }^{{ }^{113}}$ In her analysis, Scott goes even further. By applying a 'governmentality' perspective, ${ }^{114}$ she highlights the acknowledgement of the power dimension in order to explain why the assessment process may not produce the benign outcomes that one may expect from the assertion of a 'SEA - good governance' nexus. ${ }^{115}$ These observations indicate that when assessing the role of SEA as a policy tool for improving governance, one needs to apply a broad and multilayered perspective. ${ }^{116}$

Returning to the legal context of the SEA Protocol, it is too early for a fair evaluation of its impact given its recent entry into force. Obviously, legal frameworks and administrative arrangements have been introduced and are available as the SEA Protocol provides for an international legally binding character of SEA for the parties to the Protocol. This ensures that all relevant stakeholders and actors may get involved in national (and transboundary) SEA processes. This raises expectations about the quality of the interactions in these processes as they could ultimately be challenged before

${ }^{112}$ K. Verhoest, B. Verschuere, F. Meyers and A. Sulle, 'Performance of Public Sector Organizations: Do Managerial Tools Matter?', in P. Laegreid and K. Verhoest, n. 11 above, 231. See also S.H. Stringham, 'Does Quality Management Work in the Public Sector?', 9:3 Public Administration and Management (2004), 182; and R. Vinni, 'Total Quality Management and Paradigms of Public Administration', 8:1 International Public Management Review (2007), 103, at 125, found at <http://www.idt.unisg.ch/org/idt/ipmr.nsf/0/769fff3d993b69 f5c12572bc0048154f/\$FILE/Vinni_Volume_8_Issue_1.pdf >.

${ }^{113}$ S. Everett, 'The Policy Cycle: Democratic Process or Rational Paradigm Revisited?', 62:2 Australian J. Public Administration (2003), 65, at 70, who states: '[B]ureaucrats and public administrators do not make the paradigm - they implement it - and in this case the paradigm is government policy and the focus of the administrator is a mechanism which smoothly sets this in place.' See also the reaction by P. Bridgman and G. Davis, 'What Use is a Policy Cycle? Plenty, if the Aim is Clear', 62:3 Australian J. Public Administration (2003), 98, at 98-102.

${ }^{114}$ Michel Foucault introduced the term 'governmentality' in the 1970s in the course of his investigations of political power. It was 'understood in the broad sense of techniques and procedures for directing human behaviour. Government of children, government of souls and consciences, government of a household, of a state, or of oneself'. See N. Rose et al., 'Governmentality', Sydney Law School, Legal Studies Research Paper No. 09/94 (September 2009), found at $<$ http://ssrn.com/abstract=1474131 $>$.

${ }^{115}$ C. Scott, 'Governmentality and Strategic Environmental Assessment: Challenging the SEA/Good Governance Nexus', 13:1 J. Environmental Assessment Policy and Management (2011), 67.

${ }^{116}$ O. Bina, 'A Critical Review of the Dominant Lines of Argumentation on the Need for Strategic Environmental Assessment', 27:7 Environmental Impact Assessment Review (2007), 585, at 602. 
an administrative court or the International Court of Justice. ${ }^{117}$ In the meantime, an updated and improved resource manual, which looks beyond SEA, could support and enhance compliance. However, the first Meeting of the Parties to the SEA Protocol has not given an ambitious signal in this regard and the publication of the latest edition of the Manual does not indicate significant improvements in this direction from the previous version. ${ }^{118}$

As the $\mathrm{EU}$ is the area with the longest and most diverse experience with SEA, it may provide the best evidence of the likely effectiveness of the SEA Protocol. However, the 2009 Commission Report on the application and effectiveness of the Directive on Strategic Environmental Assessment suggests that the application of SEA in the Member States is only in its infancy: '[F]urther experience is needed before deciding on whether the Directive should be amended and, if so, how this should be done. [Member States] seem to prefer stability in the legislative requirements, to allow SEA systems and processes to settle down and provide the opportunity to establish robust ways of using SEAs to improve the planning process. ${ }^{119}$

This report also addressed differences with the SEA Protocol and it says that the entry into force of the Protocol may result in changes to the SEA Directive. Moreover, the scope of the SEA Protocol goes further than the SEA Directive in that it encourages potential application to certain policies and legislative proposals, which is not the case in the SEA Directive. This issue was briefly mentioned in an opinion of the Advocate General of the European Court of Justice: 'Although no mandatory obligation to subject legislative proposals to environmental assessment can be inferred from that provision, the parties to the Protocol, including therefore the European Union, clearly consider such an assessment to be possible and appropriate. ${ }^{120}$ Thus, the

\footnotetext{
117 See A. Van Buuren and S. Nooteboom, n. 111 above, at 135.

118 UNECE, n. 67 above.

${ }^{119}$ Part 8 of the Report contains the findings and recommendations. See European Commission, DG ENV, Study concerning the report on the application and effectiveness of the SEA Directive (2001/42/EC) (April 2009), at 132, found at <http://eur-lex.europa.eu/LexUriServ/ LexUriServ.do?uri=CELEX:52009DC0469:EN:NOT>.

120 Opinion of Advocate General Kokott of 4 March 2010, Joined Cases C-105/09 and C-110/09, Terre wallonne ASBL v. Région wallonne and Inter-Environnement Wallonie ASBL v. Région wallonne, [2010] ECR I-0561. This case concerns references for a preliminary ruling from the Belgian Conseil d'Etat. This opinion states, at paragraph 44 , that:
}

The Protocol on Strategic Environmental Assessment, ... an international agreement of the European Union within the UN-ECE framework, similarly shows that the environmental
SEA Protocol may stimulate the inclusion of policies and legislation in the application of the SEA Directive as an option to improve future governance in the EU.

The SEA Directive and the SEA Protocol are recent outcomes of (ongoing (post-)NPM) public management reforms to improve the performance of governmental levels with a particular focus on the integration of environmental policies. The legal SEA frameworks, however, are just elementary tools for guiding the SEA implementation activities performed by civil servants and other stakeholders. Like other (ex post and ex ante, e.g., Regulatory Impact Assessment) evaluation approaches, SEA should contribute to more evidencebased policies. The requirements for information and transparency are core features which generate challenges not only for public administrations, but also for 'end users': citizens, business as well as politicians. An analysis of experiences with other public management innovations might provide useful input regarding further expectations about the performance of SEA processes, including their limits. ${ }^{121}$

Jan De Mulder works as Public Governance counsel with the Representation of the Government of the Region of Flanders (Belgium) to the European Union. Previously he worked as legal counsel with the Flemish Environment Administration and participated as Belgian delegate, inter alia, in the negotiations on the SEA Directive and the SEA Protocol. He chaired the first and second meetings (June 2004, April 2005) of the Signatories of the SEA Protocol. He is also engaged as voluntary researcher with the Department of Public International Law, University of Ghent, Belgium. assessment of legislative measures is not a distant prospect. Article 13(1) requires the contracting parties to endeavour to ensure that environmental, including health, concerns are considered and integrated to the extent appropriate in the preparation of their proposals for policies and legislation that are likely to have significant effects on the environment, including health. The aim in this context is not only to integrate the environment into the considerations in some form or other, but, according to Article 13(2), also to ensure that the appropriate principles and elements of the Protocol are considered.

${ }^{121}$ C. Radaelli and A. Meuwese, 'Better Regulation in Europe: Between Public Management and Regulatory Reform', 87:3 Public Administration (2009), 639. The observations in this article offer an interesting perspective for comparative reflections about the public management context of SEA. 